\title{
Correction: One week of levofloxacin plus dexamethasone eye drops for cataract surgery: an innovative and rational therapeutic strategy
}

\author{
Francesco Bandello - Marco Coassin - Antonio Di Zazzo - Stanislao Rizzo • llaria Biagini - Nadezhda Pozdeyeva • \\ Maksim Sinitsyn - Alexander Verzin · Pasquale De Rosa • Francesco Calabrò • Teresio Avitabile • Vincenza Bonfiglio • \\ Francesco Fasce - Rafael Barraquer • Josè Lamarca Mateu - Thomas Kohnen (i) - Marino Carnovali • Boris Malyugin • \\ Group LEADER-7 Investigators
}

Published online: 28 May 2020

(c) The Author(s) 2020. This article is published with open access

\section{Correction to: Eye}

$$
\text { https://doi.org/10.1038/s41433-020-0869-1 }
$$

In the original Article, co-author Dr. Thomas Kohnen's surname was misspelled as "Khonen". This has been corrected in the PDF, HTML and XML versions of this article.
Open Access This article is licensed under a Creative Commons Attribution 4.0 International License, which permits use, sharing, adaptation, distribution and reproduction in any medium or format, as long as you give appropriate credit to the original author(s) and the source, provide a link to the Creative Commons license, and indicate if changes were made. The images or other third party material in this article are included in the article's Creative Commons license, unless indicated otherwise in a credit line to the material. If material is not included in the article's Creative Commons license and your intended use is not permitted by statutory regulation or exceeds the permitted use, you will need to obtain permission directly from the copyright holder. To view a copy of this license, visit http://creativecommons. org/licenses/by/4.0/. 